\title{
Assessing Localized Contamination Hazard and Groundwater Quality Challenges in Water-Stressed Peri-Urban Accra, Ghana
}

\author{
Stephen Twumasi Annan1", Bright Frimpong2, Collins Owusu-Fordjour ${ }^{1}$, Bismark Yeboah Boasu ${ }^{3}$ \\ ${ }^{1}$ Department of Integrated Science Education, Faculty of Science Education, University of Education, Winneba, Ghana \\ ${ }^{2}$ Department of Programmes, Planning, Monitoring and Evaluation, Environmental Protection Agency, Accra, Ghana \\ ${ }^{3}$ Department of Environment and Resource Studies, SD Dombo University of Business and Integrated Development Studies, Wa, \\ Ghana \\ Email: *stwumasiannan@yahoo.com
}

How to cite this paper: Annan, S. T., Frimpong, B., Owusu-Fordjour, C., \& Boasu, B. Y. (2022). Assessing Localized Contamination Hazard and Groundwater Quality Challenges in Water-Stressed Peri-Urban Accra, Ghana. Journal of Geoscience and Environment Protection, 10, 13-28. https://doi.org/10.4236/gep.2022.101002

Received: October 21, 2021

Accepted: January 4, 2022

Published: January 7, 2022

Copyright $\odot 2022$ by author(s) and Scientific Research Publishing Inc. This work is licensed under the Creative Commons Attribution International License (CC BY 4.0).

http://creativecommons.org/licenses/by/4.0/

\section{(c) (i) Open Access}

\begin{abstract}
The study assesses the quality of hand dug wells in relation to distance from soakaway septic tanks in three selected peri-urban communities in the $\mathrm{Ga}$ West Municipality near Accra, Ghana. Water quality analyses of bio-physicochemical variables $(\mathrm{pH}$, Temperature, EC, turbidity, DO, BOD, TSS, TDS, sodium, potassium, nitrate, nitrite, ammonia, sulphate, chloride, salinity, total alkalinity, total coliform, fecal coliforms and isolation of $E$. coli) were determined. Concentrations of the major nutrient anion sulphate, nitrate, phosphate, and chlorides in water samples at distances between $0-30 \mathrm{~m}$ radial distances from the septic tank were above the WHO permissible limit of drinking water compared to the control. All the water samples had high fecal and total coliform counts that exceeded the international standard of 0 per $100 \mathrm{~mL}$ of potable water with counts ranging from $0-143 \mathrm{cfu} / 100 \mathrm{ml}$ and 53 $463 / 100 \mathrm{ml}$ for FC and TC respectively. High fecal coliform and detection of $E$. coli in most samples is an indication of fecal pollution possibly from their close proximity to soak away septic sewage. The high nutrient levels detected in samples at distances between $0-30 \mathrm{~m}$ as compared to the controls may also be attributed to its close proximity to septic tanks. This study, therefore, accentuates the need for the owners of the water points to site their water source at least $30 \mathrm{~m}$ away from localized sources of pollution as well as treatment of groundwater before use.
\end{abstract}

\section{Keywords}

Groundwater, Water Quality, Localized Contamination, Peri-Urban 


\section{Introduction}

Water is vital for life, well-being, food security and socio-economic development of mankind though, nearly half of all people in both developed and developing countries have problems with water contamination (Li et al., 2021), including infections or diseases associated with inadequate water supply ( $\mathrm{Li} \& \mathrm{Wu}, 2019$; Bartram et al., 2005), and the poor sources of water supply (Schweitzer \& Noblet, 2018; Robertson et al., 1995). This phenomenon does not only threaten the health of humankind but also the sustainability of nations' socio-economic development ( $\mathrm{Li}$ et al., 2021; Li \& Wu, 2019). Water can be found both underground and on the surface of the earth (Aremu et al., 2011) which respectively referred to as groundwater well, boreholes, springs) and surface waters (rivers, streams and ponds). Previous studies have concentrated on the causes and effects of groundwater contamination (Li et al., 2021; Lesser et al., 2018; Addo et al., 2011; Elumalai et al., 2020; Li \& Wu, 2019; Schweitzer \& Noblet, 2018; Aremu et al., 2011) with little attention paid to the contamination hazards and groundwater quality measurement challenges which this study aims at. Groundwater serves as a major source of water supply for almost one-third of the world population (International Association of Hydrogeologists, 2020). In Ghana, majority of the people and especially the rural dwellers depend on groundwater and surface waters and sometimes rain-water as their main sources of water supply for domestic, agricultural and industrial uses (Tay, 2008). As the population grows and urbanization increases, more water is required and greater demand is put on ground and surface water. It is often a belief that groundwater has an excellent microbiological and physico-chemical quality though, several anthropogenic activities pollute groundwater resources (Elumalai et al., 2020; Lesser et al., 2018; Schweitzer \& Noblet, 2018; Aremu et al., 2011). Groundwater pollution has been attributed to the process of industrialization and urbanization that has progressively developed over time ( $\mathrm{Li}$ et al., 2021) without any regard for environmental consequences which eventually results in the deterioration of physical, chemical and biological properties of water (Addo et al., 2011).

The study area has lower to middle class settlements and for well over a decade experienced rapid spatial development in the form of residential and office accommodation due, in part, to increasing population, rural-urban and transnational migration into the city, increased trading and economic opportunities. These factors have, among others, fueled a boom in the construction industry as demand for land most of which are owned by families, stools and individuals' soars. Spatially, the city is qualitatively expanding at a phenomenal rate making it very difficult, if not impossible, for publicly funded and often cash strapped utility companies to keep pace with potable water supply. The Ghana Urban Water Company Limited, the agency responsible for urban and peri-urban water supply, has been constantly faulted both for the perceptibly abysmal performance and inability to provide adequate water supply to residents of Accra and its surroundings. In response to the incessantly acute shortage and erratic water 
supply experienced in the city, many households resort to privately constructed shallow boreholes and hand dug wells located within the confines of homes or nearby areas to access water for domestic use (Robertson et al., 1995). Unfortunately, however, these homes also tend to host septic tanks and drainage that channel various forms of human and waste water directly into the ground. Such discharges therefore have the potential to directly and rapidly contaminate local groundwater sources without much time for natural remediation by soils and rocks. In addition, the proximities of boreholes and wells which serve as groundwater sources outside homes in many peri-urban areas are also often sites for unauthorized dumping of various forms of refuse degradation of which, in a hot, humid and sub-tropical environment, could potentially release various forms of pollutants into the surrounding areas.

Gradually, groundwater resources in Ghana are experiencing an increased threat of pollution from urbanization, industrial development, agriculture and mining activities (Addo et al., 2011; Robertson et al., 1995). One significant challenge in groundwater use in the urban environment is the generation of a high volume of waste and high densities of septic tanks serviced by soakage pit drainage whose leachate may serve as a potential contaminant to aquifers. Septic tanks are very often not properly designed or sometimes sited too close to a source of water supply and eventually increase the probability of a direct connection between the septic system and the water supply (USEPA, 2009). The World Health Organization (WHO) recommends that groundwater sources should be sited at least $30 \mathrm{~m}$ away from localized contamination hazards such as septic tanks (Chukwurah, 2001). The major onsite sewage treatment systems of the entire population in the study area are septic tanks and the most assessed source of water in the municipality is groundwater accessed in a form of hand dug wells (Ga West District Assembly, 2012). Quality water remains problematic in the study area following the high incidence of water and sanitation related diseases. In 2016, for instance, the outpatient records from the municipal hospital indicated a total number of 1349, 4964 and 63 cases of typhoid fever, diarrhea and bilharzia respectively (GWMHD, 2017). The main causes of water contamination in the study area can be attributed to many factors of which septic tanks stand tall. The need to determine if septic tanks are a source of contamination to the local water supply is therefore very important to the hundreds of thousands of inhabitants in the study area that use groundwater as a drinking water source and other domestic needs. The findings of the study would be informative for future scientific work as the results would serve as baseline data in which possible water management measures would be initiated to enhance good quality of these water sources.

\section{Materials and Methods}

\subsection{Study Area}

The Ga West Municipality is located in the North Western part of Accra, Ghana. 
The Municipality lies within latitude $50^{\circ} 48^{\prime}$ North, $5^{\circ} 29^{\prime}$ North and longitude $0^{\circ} 8^{\prime}$ west and $0^{\circ} 30^{\prime}$ West respectively and occupies a land area of $284.01 \mathrm{sq} \mathrm{km}$. The projected population for Ga West Municipality for the year 2010 was 217,091 with a growth rate of $3.4 \%$. Female population represents $49.9 \%$ of the total population whilst male population was $50.1 \%$. The Municipality remains predominantly peri-urban and urban with a population growth rate of 3.4 percent in the year 2010. This implies great pressure on resources such as water (Ga West District Assembly, 2012) and sanitation facilities including public toilet. Many of the residents in the area therefore build toilet facilities in and around their houses, hence the rampant septic tanks (Figure 1). The Municipal lies wholly in the coastal savanna agro-ecological zone which supports hand dug wells and boreholes. The relief is generally undulating at less than $76 \mathrm{~m} \mathrm{(250 \textrm {ft } )}$ above sea level except for the areas around the Akuapem and Weija hills. The Rainfall pattern is bi-modal with an annual mean varying between $790 \mathrm{~mm}$ on the coast to about $1270 \mathrm{~mm}$ in the extreme north. The annual average temperature ranges between $25.1^{\circ} \mathrm{C}$ in August and $28.4^{\circ} \mathrm{C}$ in February and March. February and April are the hottest months. Humidity is generally high during the year (GWMHD, 2017).

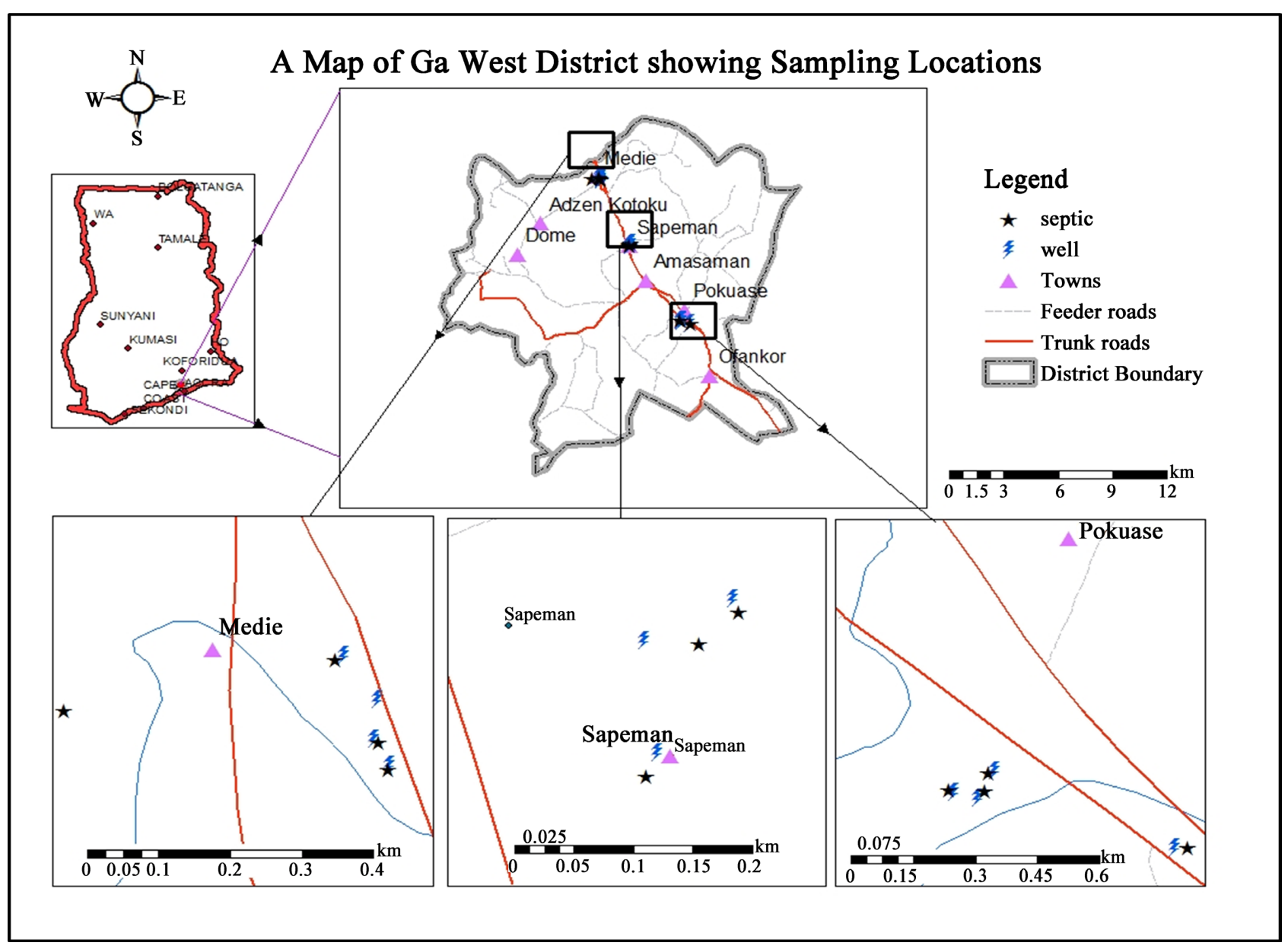

Figure 1. Map showing the spatial distribution of sampled septic tank. 
The land area is underlain by shallow rocky soils and is extensively developed on the steep slopes of the Akuapem range and the Weija hills as well as the basic gneiss inselbergs. On the Akwapim range, the soils are mainly pale and sandy with brushy quartzite occurring to the surface in most places. These soils are rich in sandstone and limestone that are good sources of material for the construction industry (Amoako et al., 2011). The red earth is usually developed in old and thoroughly weathered parent materials. They are typically loamy in texture near the surface. These conditions help to increase the volume and the availability of the groundwater in the study area.

\subsection{Sample Collection and Analysis}

A reconnaissance survey was embarked within the communities, groundwater and septic tank use questionnaire was distributed in households within the communities using snowball sampling techniques. However, in snowball sampling, a small number of individuals with the required characteristics were identified by the researcher. These people were then used to identify other people. The process continued until the required number of respondents were obtained for the study. Questions that were asked were; how many households use septic tank, what type of septic tank, the number of people in the household, the age of the septic tank, the age of the hand dug well, septic tank type, hand-dug well location (Figure 1). Based on the response and the analysis of the questionnaire, forty (40) hand dug wells sampling sites were identified with distance from the nearest septic tank being the determining factor in three purposively selected communities namely, Medie (MW), Sapeman (SW), and Pokuase (PW). The wells and boreholes to septic tank distances were categorized into three, thus: $\leq 15 \mathrm{~m}(0-15 \mathrm{~m}), 16-30 \mathrm{~m}$ and a control was taken from a community borehole at Ofankor community where there are no septic tanks or any other factors that could influence the outcome. This distance was chosen because it is recommended that septic tank should be at least $30 \mathrm{~m}$ away from borehole or hand wells (WHO, 2010). A plastic bucket was used to collect the water samples. The bucket was thoroughly washed and sterilized to avoid extraneous contamination of the samples. The samples were transferred to 40 cleaned sterilized plastic bottles. Two 1.5 litres of water were collected from each well for subsequent analysis. The geographical locations of the hand dug wells and septic tanks were geo-referenced using Global Positioning Satellite (GPS) device (Model; GARMIN etrex 20). The distances of boreholes to septic tank were also determined using a tape rule (model ZJF-100m). Data was taken at four weeks' interval within a period of three months. The physical parameters such as $\mathrm{pH}$, conductivity, temperature, salinity and turbidity were measured in situ using $\mathrm{HACH}$ model multiple parameter dataloging digital meter (Model YSI 63). Sodium and potassium were analyzed employing flame emission photometric methods whilst chloride was analyzed using Agentometric methods. Total alkalinity was determined titrimetically using potentiome- 
tric methods (Amoako et al., 2011). DO was measured with a DO meter and BOD was analyzed using titrimetric methods (Azide modification of Winkler method). Nitrate, nitrite, ammonia, phosphate, sulphate and total suspended solids were determined using $\mathrm{HACH}$ direct reading spectrophotometer. Total coliform (TC) and fecal coliform (FC) were analyzed using the cellulose membrane filtration technique (Amoako et al., 2011).

\subsection{Quality Assurance}

Proper quality assurance procedures and precautions were taken to ensure the reliability of the results. Samples were carefully handled to avoid any external influences that could contaminate the sample. Triplicate determinations of the samples were made and the data was presented as means. Glasswares were properly cleaned, and reagents were of analytical grades. Deionized water was used throughout the study. For the spectrophotometric analysis, reagent blank determinations were used to correct the instrument readings. For validation of the analytical procedure, repeated analysis of the samples against internationally certified/standard reference material (SRM-1570) of National Institute of Standard and Technology were used. With the exception of temperature, multi probe meters were calibrated together using the same standard and procedures. Electrical conductivity was calibrated against $0.005,0.05$ and $0.5 \mathrm{M}$ standard potassium chloride solution; $\mathrm{pH}$ was calibrated with standard buffer at $\mathrm{pH}$ of 4 and 9.2. Dissolved oxygen (DO) was calibrated against zero solution of sodium sulphate. Temperature was checked against standard mercury thermometer for consistency. The overall analytical procedure was validated by systematic recovery experiments performed. A recovery value ranging from $80.5 \% \pm 0.8 \%$ to $88.7 \% \pm 2.3 \%$ was obtained which was an excellent acceptance. Regarding the methodologies, relative percentage standard deviation was $8 \%$ indication good precision. These results comply with the criterion of acceptability (RSD < 10\%).

\subsection{Statistical Analysis}

Raw data collected for physico-chemical and bacteriological was analyzed using stata software version 16 . The means, standard deviations, maximum, and minimum and ranges for the various parameters were computed. One-way Analysis of Variance (ANOVA) was used to test for the significant difference among sampling sites and statistical significance was accepted at $p<0.05$. Pearson Product Moment Correlation coefficient (PPMCC) was used to determine the direction and strength among the physical and chemical parameters.

\section{Results and Discussion}

\subsection{Physico-Chemical Parameters}

Table 1, summarizes the results of the physico-chemical and bacteriological parameters of the water samples collected during the study period. 
Table 1. Physico-chemical and bacteriological characteristics of hand dug-well water samples.

\begin{tabular}{ccccccc}
\hline Parameters & Units & Minimum & Maximum & Mean & $\begin{array}{c}\text { EU } \\
\text { Standards }\end{array}$ & $\begin{array}{c}\text { WHO } \\
\text { Standards }\end{array}$ \\
\hline pH & Ph units & 6.3 & 7.2 & 6.7 & $6.5-9.5$ & $6.5-8.5$ \\
Temperature & ${ }^{\circ} \mathrm{C}$ & 28.2 & 31.8 & 29.5 & - & $22-27$ \\
Conductivity & $\mu \mathrm{S} / \mathrm{cm}$ & 675.3 & 5393.7 & 3672 & 250 & 250 \\
TDS & $\mathrm{mg} / \mathrm{l}$ & 439.4 & 2929.9 & 2276.4 & - & 1000 \\
TSS & $\mathrm{mg} / \mathrm{l}$ & 11.3 & 33.7 & 18.3 & 500 & 500 \\
Turbidity & $\mathrm{NTU}$ & 1.7 & 6 & 2.7 & 5 & 5 \\
Salinity & $\mathrm{mg} / \mathrm{l}$ & 300 & 2300 & 1330 & - & 200 \\
Nitrate & $\mathrm{mg} / \mathrm{l}$ & 2.2 & 19.6 & 12.5 & 50 & 10 \\
Nitrite & $\mathrm{mg} / \mathrm{l}$ & 0.002 & 0.019 & 0.001 & 1 & 1 \\
Ammonia & $\mathrm{mg} / \mathrm{l}$ & 0.01 & 0.16 & 0.04 & 0.5 & 0.5 \\
Sodium & $\mathrm{mg} / \mathrm{l}$ & 6.3 & 43.1 & 33 & 200 & 200 \\
DO & $\mathrm{mg} / \mathrm{l}$ & 4 & 6.8 & 4.6 & 8.5 & 7.5 \\
BOD & $\mathrm{mg} / \mathrm{l}$ & 0.7 & 3.3 & 1.7 & 0 & 0 \\
Sulphate & $\mathrm{mg} / \mathrm{l}$ & 17.7 & 491.7 & 190.2 & 250 & 250 \\
Total Alkalinity & $\mathrm{mg} / \mathrm{l}$ & 22 & 399 & 142 & - & 400 \\
\hline & & & & & & \\
\hline
\end{tabular}

\section{2. $\mathrm{pH}$ and Temperature}

The $\mathrm{pH}$ of the water sample ranged from 6.4 to 7.2. With the exception of one site at Medie community sited at distance between $0-15 \mathrm{~m}$ that recorded $\mathrm{pH}$ value of 6.3, all the other water samples were within the WHO and Ghana water standard range for portable water of 6.5 - 8.5 (Table 1). The results obtained indicate neutral to alkaline conditions and it is not surprising since, according to Amoako et al. (2011), the bedrock of the area is rich in limestone and sandstone which contains higher levels of carbonate and bicarbonates ions that may act as a buffer and hence resist acidity. The mildly acidic $\mathrm{pH}$ levels recorded in some sites may be due to presence of high level of organic matter within the soil zones whose oxidation releases carbon dioxide that reacts with water to produce a weak carbonic acid (Langmuir, 1997). According to Nkansah et al. (2010) pH values lower than 6.5 are considered too acidic for human consumption and can cause significant health problems such as acidosis and adverse effects on digestive and lymphatic system. A drop in $\mathrm{pH}$ could also be harmful since heavy metals have higher dissolution in low $\mathrm{pH}$ waters and thus could contain elevated levels of toxic metals posing a health hazard to consumers. Low $\mathrm{pH}$ can cause damages to metal piping and staining of laundry. It was also observed from the study that $\mathrm{pH}$ correlates positively with chlorides which is of health concern. The water temperature did not show any significant variation in relation to dis- 
tance. Temperature ranged from $28.2^{\circ} \mathrm{C}$ to $31.8^{\circ} \mathrm{C}$. The natural background limit for (WHO, 2010) is between $22^{\circ} \mathrm{C}$ to $27^{\circ} \mathrm{C}$ (Figure 1). The temperature values obtained from sampled water for the entire study period were slightly above the natural background limit. Temperature is a critical factor of significant importance for aquatic ecosystem as it affects the water organism as well as the physico-chemical properties of water (Nkansah et al., 2010). The high temperature recorded may be due to active microorganism activities in the water or the different depth with which the samples were taken.

\subsection{Conductivity, Total Dissolved Solids}

Electrical conductivity is the measure of the total dissolved ions in water. Conductivity of the water sample ranged from $675.3-5393.7 \mu \mathrm{S} / \mathrm{cm}$. All the values recorded during the study period were above the WHO regulatory limit of 250 $\mu \mathrm{S} / \mathrm{cm}$. The high values indicated that the dissolved ions were too high for human consumption. TDS is a measure of the total organic and inorganic substances dissolved in water (ANZECC, 2000). The TDS of the sample ranged from $439.4 \mathrm{mg} / \mathrm{l}$ to $2929.9 \mathrm{mg} / \mathrm{l}$. With the exception of control sites at Sapeiman and Pokuase that recorded $439.4 \mathrm{mg} / \mathrm{l}$ and $751.5 \mathrm{mg} / \mathrm{l}$ respectively, all the other sites between $0-15 \mathrm{~m}$ and $16-30 \mathrm{~m}$ exceeded the WHO guideline limit of 1000 $\mathrm{mg} / \mathrm{l}$.TDS above $1000 \mathrm{mg} / \mathrm{l}$ may be objectionable to consumers. The high levels of conductivity and TDS may be due to natural geochemistry of the study area since some of the controlled sites also recorded slightly above the recommended limits. A total suspended solid relatively measures the visual observation of water sample. The TSS of the sampled water ranged from $13.7 \mathrm{mg} / \mathrm{l}$ to $33.7 \mathrm{mg} / \mathrm{l}$ indicating an excellent measure of the quality of the water for human consumption. According to $\mathrm{WHO}$ value guideline, water must have a TSS value not exceeding $500 \mathrm{mg} / \mathrm{l}$ for it to be considered safe. The values of TSS recorded for the entire study period were within the recommended limit. These results are indeed not surprising because TSS in ground water have mostly been found to be very low (Amoako et al., 2011). This is a result of the filtering capacity of the soil and earth materials that the water pass through. Therefore, as the water gets to the aquifer, most suspended materials are effectively attenuated. The WHO guideline for turbidity in drinking water is 5 NTU (Nephrometic turbidity units). The turbidity of the water sample ranged from 1.7 NTU to 6 NTU. With the exception of one site at Sapeiman that recorded a mean turbidity of 6 NTU, all the other sites at various distances were within the WHO permissible limit. Though the value recorded is not alarming as far as this research is concern. The increase may be attributed to larger particles such as sand, clay and silt in the hand dug wells.

\subsection{Dissolved Oxygen (DO) and Biological Oxygen Demand (BOD)}

The Dissolved oxygen in the water sample ranged from $4 \mathrm{mg} / \mathrm{l}$ to $6.8 \mathrm{mg} / \mathrm{l}$. DO was generally low at sites placed at distances between $0-15 \mathrm{~m}$ and $16-30 \mathrm{~m}$ (Figure 1). The results for the DO confirms a similar values reported by (Efe et 
al., 2005) for a well water in Western Niger Delta, Nigeria where the DO ranged from 3 - $7 \mathrm{mg} / \mathrm{l}$. Though the WHO does not have a specific guideline for DO in drinking water, provisional health based guideline value of at least $7.5 \mathrm{mg} / \mathrm{l}$ have been provided for the purpose of public health protection (WHO, 2010). Almost all the samples recorded for the entire study period had their DO values below the guideline value. Dissolved oxygen is a very important parameter for the survival of aquatic organism and is used as a measure for the freshness of water. The low DO record in the water samples may be due to high levels of oxidizable substances in the water such as sulphur and nitrogen which are oxidized to sulphate and nitrate respectively. The decomposition of organic matter as well as some dissolved gases could also be a possible outcome. The high temperature recorded for the study could also not be rule out as high temperature encourages active microorganisms in the water that consumes oxygen. This low Do levels may encourage anaerobic respiration activities and may lead to bad odour in the water. The BOD in the water sample ranged from $0.7 \mathrm{mg} / \mathrm{l}$ to $3.3 \mathrm{mg} / \mathrm{l}$. Biological oxygen demand (BOD) is a measure of organic matter contamination of water and therefore a good measure of the relative oxygen depleting effect of biodegradable pollutants in water. According to WHO (2010), water considered to be safe for drinking purposes should have a BOD of zero. Though the BOD at the control sites were relatively lower compared to the other sampling sites all the values fell above the WHO permissible zero limit rendering the water sample unsuitable for drinking purposes as it could pose health problem. The higher levels recorded may be due to the low level of dissolved oxygen recorded over the period as DO is required to oxidize organic materials in the water. There was a weak negative correlation between $\mathrm{DO}$ and BOD over the entire study period with a correlation coefficient of 0.325 , however, the use of the water without treatment may pose a health hazard.

\subsection{Ions and Nutrients}

\subsubsection{Chloride, Sulphate and Phosphate}

The concentration of chloride found in the water sample ranged from $72.6 \mathrm{mg} / \mathrm{l}$ to $1336.5 \mathrm{mg} / \mathrm{l}$ (Figure 2). The WHO permissible limit for chloride in drinking water is $250 \mathrm{mg} / \mathrm{l}$. The mean chloride values in all the control sites fell within the WHO permissible limit but the sites at distances $0-30 \mathrm{~m}$ from the nearest septic tank recorded higher levels far above the permissible limits. It was observed from the study that the concentrations of chloride in water samples at distances from 0 - $30 \mathrm{~m}$ were about four times higher than the WHO permissible limit of $250 \mathrm{mg} / \mathrm{l}$ and also about three times higher than the control sites According to Amoako et al. (2011) higher levels of chloride in water may not have a health problem but effect depends on the associated cation such as sodium, calcium, magnesium and potassium. The greatest effect is the objectionable salty taste if it combines with sodium ions forming sodium chloride in excess of $200 \mathrm{mg} / \mathrm{l}$. From the study chloride was found to have a significant strongly positive correlation with conductivity, TDS, $\mathrm{pH}$, sodium, salinity and sulphate and this is of 


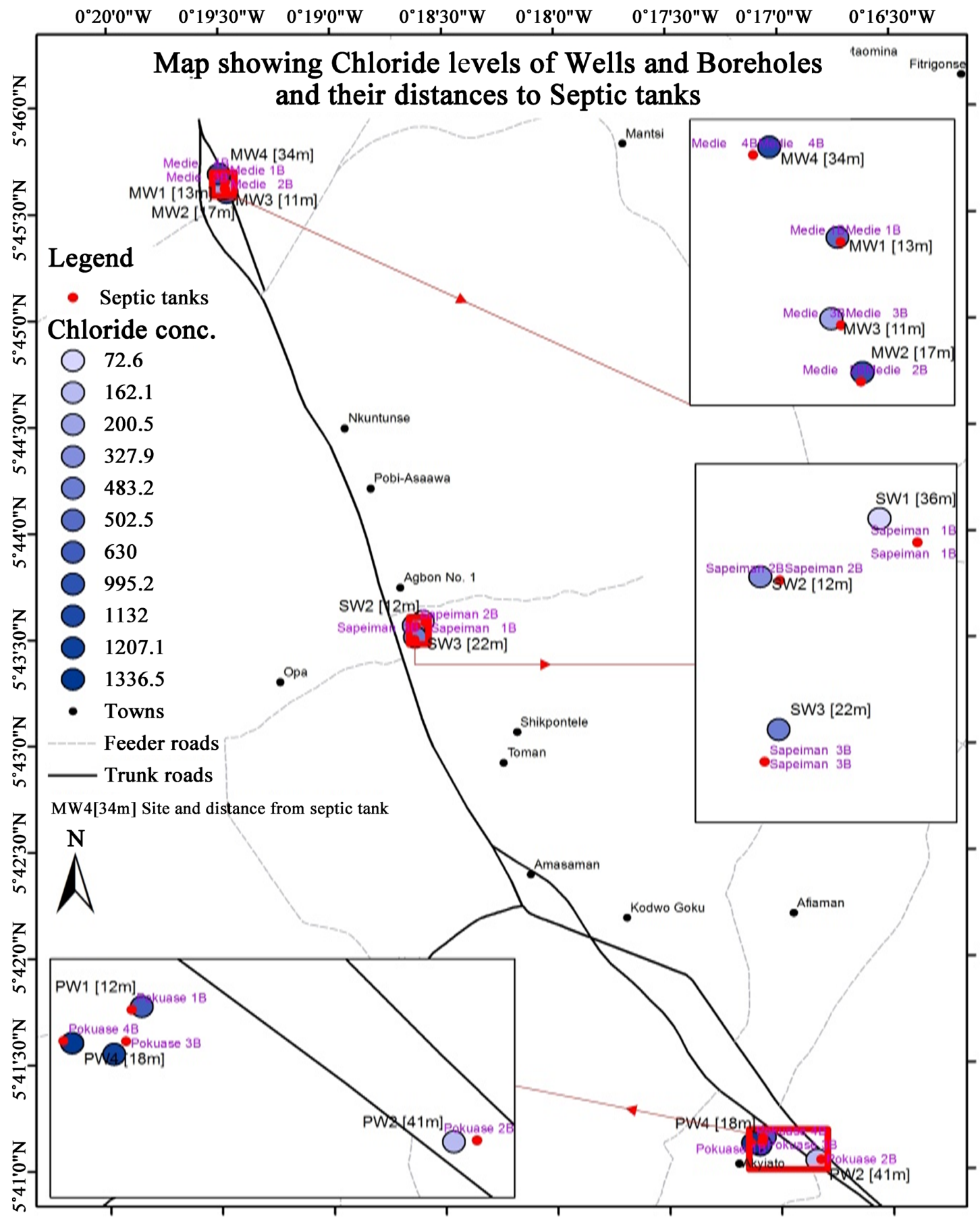

Figure 2. Map showing mean variation of chloride in groundwater in relation to distance from septic tank.

significant health concern as it can lead to corrosion of metal pipes. The Department of National Health and Welfare, Canada (1978) reported that chlorides in surface and ground water may result from both natural and anthropogenic sources such as run off containing salts, the use of mineral fertilizers, septic tank effluent, industrial leachate, intensive irrigation and sea water intrusion in areas close to the sea. The results obtained in this study agrees with a similar research work by (Addo et al., 2011) on ground water from wells in the Eastern region of 
Ghana who also reported a mean chloride levels between $87.97 \mathrm{mg} / \mathrm{l}$ to 5142.1 $\mathrm{mg} / \mathrm{l}$. The higher chloride levels obtained in this research work may be attributed to the natural geochemistry of the area but since the control samples recorded lower levels then some anthropogenic factors might be at play. This may be due to the proximity of those wells to the septic tank since human wastes contain high levels of chloride salts.

Sulphate is also nontoxic anion that is of significant health concern. The mean sulphate concentration ranged from $17.7 \mathrm{mg} / \mathrm{l}$ to $491.7 \mathrm{mg} / \mathrm{l}$ (Table 1). The WHO recommends that concentrations of sulphate higher than $250 \mathrm{mg} / \mathrm{l}$ should be reported to health authorities due to problem with catharsis, dehydration, gastrointestinal and digestive problems (WHO, 2010). Excess sulphate in water is also known to cause a laxative effect and also induce a bitter taste. About $60 \%$ of the water sample at sites between $0-15 \mathrm{~m}$ and $16-30 \mathrm{~m}$ had sulphate above the permissible limits. According to Manivaskam (2005) sulphate occurs naturally in water as a result of leaching from rocks salt). Increasing levels however may be attributed containing calcium sulphate (gypsum), sodium sulphate and magnesium sulphate (Epson to anthropogenic effects with which the source to indict in this research may be due to the proximity of the wells to the nearest septic tank.

Phosphorus phosphate $\left(\mathrm{PO}_{4}-\mathrm{P}\right)$ is a limiting nutrient for algae growth and a major cause of eutrophication in surface waters. This is a biological effect in which there is a successive increase in the concentration of plant nutrients and it therefore controls primary productivity of a water body (Karikari et al., 2007). The presence of phosphate in water is a significant indicator of anthropogenic pollution. The phosphate level in the water sample ranged from $0.18 \mathrm{mg} / \mathrm{l}$ to 1.1 $\mathrm{mg} / \mathrm{l}$ (Figure 3). Though the WHO does not have specific guideline, for pristine natural waters levels ranged from $0.005-0.020 \mathrm{mg} / \mathrm{l}$. The phosphate levels in the controlled samples were generally lower and fell within the WHO permissible limit as compared to the sites with distances $0-30 \mathrm{~m}$ whose phosphate level exceeded the permissible limit and the levels in most natural waters Phosphate may not be toxic to humans unless they are present in very high levels where digestive problems could occur. According to Pieterse et al. (2003) phosphorus in a form of orthophosphate may be present in septic tanks systems due to phosphorus rich human excrement or phosphate detergents and cleaning products. Therefore, the source to indict the increasing levels may probably be the proximity of septic tanks to the water source.

\subsubsection{Nitrate, Nitrite}

The Nitrate nitrogen levels recorded during the entire study period ranged from $2.2 \mathrm{mg} / \mathrm{l}$ to $19.6 \mathrm{mg} / \mathrm{l}$. With the exception of water samples obtained from four site at Medie and three at Sapeiman at $0-30 \mathrm{~m}$ that recorded a mean value above recommended limit, water samples from other sites fell within the WHO maximum contamination level (MCL) of $10 \mathrm{mg} / \mathrm{l}$ (Figure 1). The presence of these nutrients in water is in indication of recent or remote fecal pollution. According to Baird (1999), high levels of nitrate in water are directly associated 


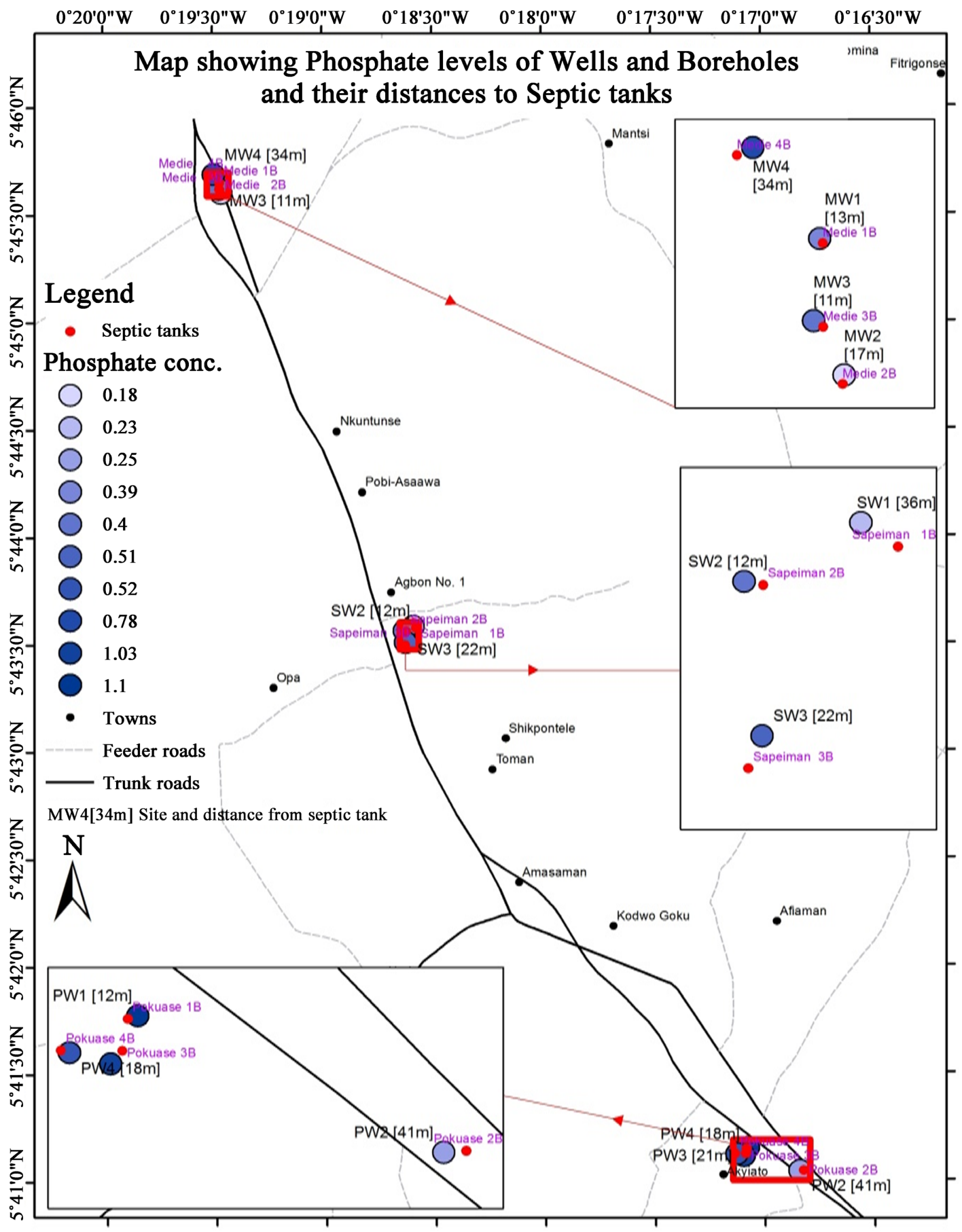

Figure 3. Map showing mean variation of phosphate in groundwater in relation to distance from septic tank.

with Methemoglobaenimia or infant cyanosis, an acute condition which is most frequently found among bottle-fed infants less than three months of age. Nitrates have also been known to cause ailment like diarrhea and have also been suggested as a known carcinogen when it combines with amines to form nitrosamines by a number of researchers. According to Robertson et al. (1995) Nitrates are conservative in shallow ground water hence its presence could be associated with anthropogenic factors such as animal waste, human waste and min- 
eral fertilizers. For the purpose of this research the increasing levels recorded in the samples may probably be due to the proximity of the wells to the nearest septic tank. Nitrite-nitrogen is also a contaminant of significant health risk in water and hence need to be regulated in water. Nitrite in water is an indicator of biological pollution (Addo et al., 2011). WHO has adopted $1 \mathrm{mg} / \mathrm{l}$ as the maximum contaminant level (MCL) for Nitrite nitrogen in water. The Nitrite levels ranged from $0.01 \mathrm{mg} / \mathrm{l}$ to $0.198 \mathrm{mg} / \mathrm{l}$. The levels recorded during the entire study period fell within the permissible limit and are not alarming to consumers of the water.

\subsubsection{Total Alkalinity, Salinity}

Alkalinity of water is its capacity and ability to resist changes in acidity. Total alkalinity for portable drinking water, according to WHO, is $400 \mathrm{mg} / \mathrm{l}$. The total alkalinity levels in the water sample ranged from $22 \mathrm{mg} / \mathrm{l}$ to $399 \mathrm{mg} / \mathrm{l}$. The concentrations in the water for the entire study period fell within the WHO permissible limit. Alkalinity of $500 \mathrm{mg} / \mathrm{l}$ is also accepted by the USEPA and Ghana water company (GWC). The major ionic species that contribute to alkalinity in water include carbonates, bicarbonates, hydroxides, phosphates, borate and organic acids. The low levels of alkalinity recorded for the entire study period may be attributed to the geology of the study area as according to Addo et al. (2011) the area is characterized by sedimentary rocks comprising of limestone and sandstone which is very rich in carbonates and bicarbonates. Salinity is a measure of the total soluble or dissolved salt in water. It is normally a measure of the total dissolved solids or the electrical conductivity of the water. According to WHO, water that is considered to be safe for human consumption should not have salinity levels exceeding $200 \mathrm{mg} / \mathrm{l}$ otherwise it will induce a salty taste in the water. Salinity levels in the water ranged from $300 \mathrm{mg} / \mathrm{l}$ at controlled distances to $2300 \mathrm{mg} / \mathrm{l}$ at distances between $0-30 \mathrm{~m}$. All the water samples analyzed for the entire study period exceeded the WHO permissible limit. The high salinity in the water samples may be attributed to the high levels of conductivity and total dissolved solids recorded over the study period. The major contribution factor could be due to the geology of the study area as the controls also recorded slightly above the permissible limit.

\subsubsection{Fecal Coliform}

For water to be considered safe for human consumption, coliform bacterial and $E$. coli in the water sample should be zero. The fecal coliform counts ranged from 3 $\mathrm{cfu} / 100 \mathrm{ml}$ at controlled distance to $143 \mathrm{cfu} / 100 \mathrm{ml}$ at distances between $0-30 \mathrm{~m}$ (Figure 4). Results from the study showed high levels of total and fecal coliforms population. This is a clear indication that the septic tanks were impacting and extending their influence on the hand dug wells under investigation. The high coliform counts therefore pose a significant health problem to the consumers of the water. This result agrees with (Adentunji \& Odetokun, 2011) who reported high fecal and total coliform counts in the hand dug well sample in Nigeria. The 


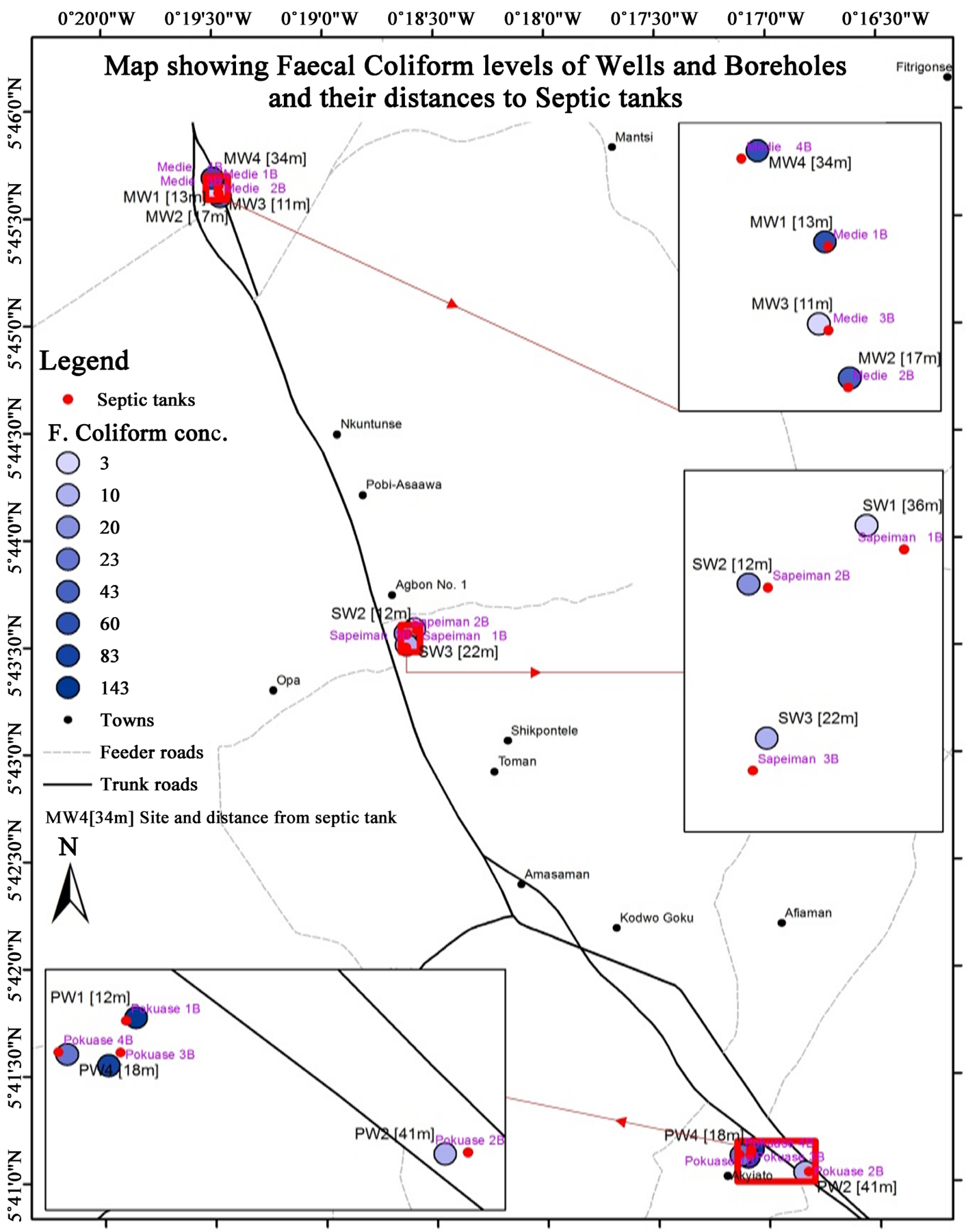

Figure 4. Map showing mean variation in groundwater faecal coliform in relation to distance from septic tank.

results indicated that all the wells sampled had high fecal and total coliform counts which exceeded the international standard of 0 per $100 \mathrm{ml}$ of portable water.

\section{Conclusion}

The concentrations of the physico-chemical parameters such as EC, TDS, and 
major nutrient ions including nitrate, chlorides and sulphate in most of the water samples at distances between $0-30 \mathrm{~m}$ were above the WHO guideline and Ghana standard limit for drinking water. Furthermore, $\mathrm{pH}$, temperature, DO, BOD, nitrite, and total alkalinity, FC, TC counts were high. This, therefore, suggests that the water had been contaminated with the fecal material possibly from the septic sewage and at risk of contamination by disease-causing pathogens. Consumption of such water should be adequately treated with chlorine or if possible boil before use. This current water quality situation, therefore, needs government intervention to ensure portable quality of water for the people in the study area.

\section{Acknowledgements}

The Authors would want to express their appreciation to the generality of the people of the study area for their invaluable support during the field work.

\section{Data Availability Statement}

Data will be available upon reasonable request of the corresponding author.

\section{Conflicts of Interest}

The authors declare no conflicts of interest regarding the publication of this paper.

\section{References}

Addo, M. A., Darko, E. O., Gordon, C. Nyarko, B. J. B., \& Gbadago, J. K. (2011). Heavy Metal Concentrations in Road Deposited Dust at Ketu-South District, Ghana. International Journal of Science and Technology, 2, 28-39.

Adentunji, V. O., \& Odetokun, I. A. (2011). Groundwater Contamination in Agbowo Community with Respect to Septic Tank Distances. Malaysian Journal of Microbiology, 7, 159-166. https://doi.org/10.21161/mjm.33011

Amoako, J., Karikari, A. Y., \& Ansa-Asare, O. D. (2011). Physico-Chemical Quality of Boreholes in Densu Basin of Ghana. Applied Water Science, 1, 41-48. https://doi.org/10.1007/s13201-011-0007-0

ANZECC (2000). Water Quality Monitoring Guidelines. Australian and New Zealand Environment and Conservation Council. https://www.waterquality.gov.au/anz-guidelines/resources/previous-guidelines/water-q uality-monitoring

Aremu, M. O., Ozonyia, G. N., \& Ikokoh, P. P. (2011). Physico-Chemical Properties of Well, Borehole and Stream Waters in Kubwa, Bwari Area Council, FCT, Nigeria. Electronic Journal of Environmental, Agricultural and Food Chemistry, 10, 2296-2304.

Baird, C. (1999). Environmental Chemistry(2nd ed.). W. H. Freeman and Company.

Bartram, J., Lewis, K., Lenton, R., \& Wright, A. (2005). Focusing on Improved Water Sanitation for Health. The Lancet, 365, 810-812. https://doi.org/10.1016/S0140-6736(05)17991-4

Chukwurah, E. I. (2001). Aquatic Microbiology. Otoba Press Limited.

Department of National Health and Welfare, Canada. (1978). Guideline for Canadian Drinking Water Quality. Supporting Documentation. DNHW. 
Efe, S. I., Ogban, F. E., Horsfall, D., \& Akporhonor, E. E. (2005). Seasonal Variations of Physico-Chemical Characteristics in Water Resources Quality in Western Niger Delta Region, Nigeria. Journal of Applied Sciences and Environmental Management, 9, 191-195.

Elumalai, V., Nethononda, V. G., Manivannan, V., Rajmohan, N., Li, P., \& Elango, L. (2020). Groundwater Quality Assessment and Application of Multivariate Statistical Analysis in Luvuvhu Catchment, Limpopo, South Africa. Journal of African Earth Sciences, 171, Article ID: 103967. https://doi.org/10.1016/j.jafrearsci.2020.103967

Ga West District Assembly (2012). Strategic Environmental Assessment Report. Ga West District Assembly.

GWMHD (2017). Strategic Environmental Assessment Report. Ga West District Assembly.

International Association of Hydrogeologists (2020) Groundwater-More about the Hidden Resource. https://iah.org/education/general-public/groundwater-hidden-resource

Karikari, A. Y., Bernasco, J. K., \& Bosque-Hamilton, E. K. A. (2007). An Assessment of Water Quality of Augaw River in South-Eastern Coastal Plain of Ghana. West African Journal of Applied Ecology, 11, 77-87.

Langmuir, D. (1997). Aqueous Environmental Geochemical. Prentice Hall.

Lesser, L. E., Mora, A., Moreau, C., Mahlknecht, J., Hernández-Antonio, A., Ramírez, A. I., \& Barrios-Piña, H. (2018). Survey of 218 Organic Contaminants in Groundwater Derived from the World's Largest Untreated Wastewater Irrigation System: Mezquital Valley, Mexico. Chemosphere, 198, 510-521. https://doi.org/10.1016/j.chemosphere.2018.01.154

Li, P. Y., \& Wu, J. H. (2019). Sustainable Living with Risks: Meeting the Challenges. Human and Ecological Risk Assessment: An International Journal, 25, 1-10. https://doi.org/10.1080/10807039.2019.1584030

Li, P. Y., Karunanidhi, D., Subramani, T., \& Srinivasamoorthy, K. (2021). Sources and Consequences of Groundwater Contamination. Archives of Environmental Contamination and Toxicology, 80, 1-10. https://doi.org/10.1007/s00244-020-00805-Z

Manivaskam, N. (2005). Physico-Chemical Examination of Water Sewage and Industrial Effluent (5th ed.). Pragati Prakashan.

Nkansah, M. A., Boadi, M. O., \& Badu, M. (2010). Assessment of the Quality of Water from Hand-Dug Wells in Ghana. Environmental Health Insights, 4, 7-12. https://doi.org/10.4137/EHI.S3149

Pieterse, N. M., Bleuten, W., \& Jorgensen, S. E. (2003). Contribution of Point Sources and Diffuse Sources to Nitrogen and Phosphorus Loads in Lowland River Tributaries. Journal of Hydrology, 271, 213-225. https://doi.org/10.1016/S0022-1694(02)00350-5

Robertson, W. D., Harman, J., Cherry, J. A., \& Zanini, L. (1995). Impacts on a Sand Aquifer from an Old Septic System: Nitrate and Phosphorus. Groundwater, 34, 1105-1114. https://doi.org/10.1111/j.1745-6584.1996.tb02177.x

Schweitzer, L., \& Noblet, J. (2018). Water Contamination and Pollution. In B. Török, \& T. Dransfield (Eds.), Green Chemistry (pp. 261-290). Elsevier. https://doi.org/10.1016/B978-0-12-809270-5.00011-X

Tay, C. K. (2008). Chemical Characteristics of Groundwater in the Akatsi and Ketu Districts of the Volta Region, Ghana. West African Journal of Applied Ecology, 11, 1-23. https://doi.org/10.4314/wajae.v11i1.45724

USEPA (2009). National Primary Drinking Water Regulations. EPA 816-F-09-004.

WHO (2010). World Health Organization Guideline for Drinking Water Quality. WHO Summit. 